\title{
Cotton-wool spots in giant cell arteritis
}

\author{
Elisabeth De Smit BSc MBBS, Eoin O'Sullivan MD
}

Competing interests: None declared.

This article has been peer reviewed.

Affiliation: From the Eye Unit, Croydon University

Hospital, Croydon, UK

Correspondence to:

Eoin O'Sullivan,

eoin.o'sullivan@croydon

health.nhs.uk

CMAJ 2013. DOI:10.1503 /cmaj.120540
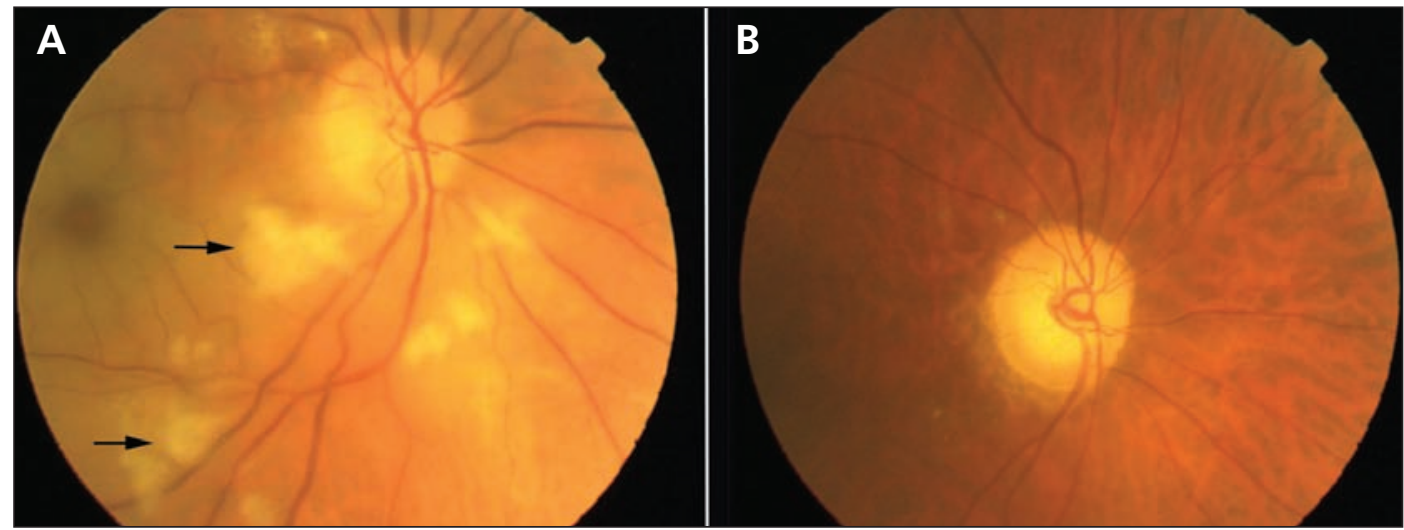

Figure 1: (A) Cotton-wool spots (arrows point to the largest ones) in the fundus of the right eye of a 71year-old woman with headache and reduced vision in her right eye. (B) The fundus 2 months later, showing complete resolution of the spots.

$\mathrm{A}$ 71-year-old woman presented with reduced vision in her right eye. She also reported having a headache, scalp tenderness and pain in her jaw when chewing. On funduscopy, multiple cotton-wool spots were observed in both eyes, more markedly in the right eye (Figure 1A). Her erythrocyte sedimentation rate was markedly elevated at $90 \mathrm{~mm} / \mathrm{h}$. Biopsy of the temporal artery confirmed giant cell arteritis. Despite high-dose intravenous treatment with steroids, her vision deteriorated in both eyes. The vision improved subsequently in her left eye but remained poor in the right eye. The systemic symptoms resolved, and her erythrocyte sedimentation rate dropped to $25 \mathrm{~mm} / \mathrm{h}$. Over the next 2 months, the cotton-wool spots resolved completely (Figure 1B).

Cotton-wool spots are found in many conditions. If present, multiple spots are typically seen in patients with hypertension, rheumatologic disease, diabetes or HIV infection. They are associated with retinal ischemia and represent localized accumulation of axoplasmic debris. Their pathogenesis is a topic of debate, and in giant cell arteritis it may be multifactorial. ${ }^{1}$

Ocular involvement occurs in up to $70 \%$ of patients with giant cell arteritis. ${ }^{2}$ The most com- mon ocular sign is anterior ischemic optic neuropathy, which presents with visual loss. A pale swollen optic disc is highly suggestive of anterior ischemic optic neuropathy from giant cell arteritis (Appendix 1, available at www.cmaj.ca/lookup /suppl/doi:10.1503/cmaj.120540/-/DC1), but absence of pallor does not exclude this diagnosis. Although cotton-wool spots may be seen in giant cell arteritis, ${ }^{2}$ they are rarely an isolated presenting sign. ${ }^{3}$ In our patient, the presence of headache, scalp tenderness, jaw claudication and an elevated erythrocyte sedimentation rate were key to making the diagnosis of giant cell arteritis.

Any patient in whom vision is threatened and the diagnosis of giant cell arteritis is suspected should be given high-dose intravenous treatment with steroids and referred for specialist management. ${ }^{4}$

\section{References}

1. Schmidt D, McLeod D. Cotton wool spots should not be regarded as retinal nerve fibre layer infarcts. Eur J Med Res 2007; 12:179-80.

2. Hayreh SS, Podhajsky PA, Zimmerman B. Ocular manifestations of giant cell arteritis. Am J Ophthalmol 1998;125:509-20.

3. Johnson MC, Lee AG. Giant cell arteritis presenting with cotton wool spots. Semin Ophthalmol 2008;23:141-2.

4. Dasgupta B, Borg FA, Hassan N, et al. BSR and BHPR guidelines for the management of giant cell arteritis. Rheumatology 2010;49:1594-7. 